\title{
BILINGUAL MATHEMATICS LEARNERS OF FOREIGN STUDENTS IN V. N. KARAZIN KHARKIV NATIONAL UNIVERSITY
}

\section{БІЛІНГВАЛЬНИЙ ПІДХІД ДО НАВЧАННЯ \\ МАТЕМАТИКИ СТУДЕНТІВ-ІНОЗЕМЦІВ У ХАРКІВСЬКОМУ НАЦІОНАЛЬНОМУ УНІВЕРСИТЕТІ ІМ. В. Н. КАРАЗІНА}

\author{
Polina BERDNIK, \\ Candidate of Technical Sciences \\ Поліна БЕРДНІК, \\ https://orcid.org/0000-0002-4022-5664 \\ bpgpma@gmail.com \\ V. N. Karazin Kharkiv National \\ Харківський національний \\ University \\ 4 Svobody Square, \\ Kharkiv, 61022 \\ університет імені В. Н. Каразіна \\ $\triangle$ пл. Свободи, 4 \\ м. Харків, 61022

\section{Pavel ONYPCHENKO,} \\ Candidate of Pedagogical Sciences, \\ Associate Professor \\ https://orcid.org/0000-0003-4497-327X \\ onipchenko.pm@gmail.com \\ Ivan Kozhedub Kharkiv National Air \\ Force University \\ $\triangle 77 / 79$ SumskaSt., \\ Kharkiv, 61023 \\ Харківський національний \\ університет Повітряних Сил \\ ПавЛО ОНИПЧЕНКО, \\ кандидат педагогічних наук, \\ доцент \\ Original manuscript received: October 20, 2019 \\ Revised manuscript accepted: December 11, 2019
}

\begin{abstract}
The article discusses the features of teaching mathematics to foreign students using English as an intermediary language for bilingual education at the Institute of International Education for study and Research of V.N. Karazin Kharkiv National University. The process of preliminary assessment of foreign students, the training program and the logic of its creation are analyzed. It describes the process of organizing bilingual education of foreign students within the faculty and its coordination between teachers. A statistical analysis of the composition of students, their initial level of training is presented and the most effective teaching strategy using the capabilities of the university teachers is substantiated. The process of creating a program in the discipline "Mathematics" is considered, taking into account the fact that students have different initial levels of knowledge in mathematics. By means of statistics, the development of the methodology of mathematicians and foreign students on the basis of a comprehensive approach to the interests of the modern
\end{abstract}


environment. From the advantages of bilingual education, it should be highlighted the academic success of students; more confident using of English speech in educational activities and for personal communication; the best career prospects; the opportunity to participate in international events and professional testing to obtain international certificates. At the further stages of learning, the free using of the English mathematical language will allow students to analyze more effectively specific business situations and make decisions verified by calculations. Thus, the using of the bilingual approach to the organization of the educational process in the study of mathematics provides an alignment between contentintegrated learning and between the personal abilities of foreign students. Bilingual education was the most suitable and effective method for the preparation of foreign students with different levels of mathematics and different languages of communication. Interdisciplinary interaction in the learning process in which students receive both professional development and improve their knowledge of a foreign language deserves a positive assessment and can be recommended for using in the educational environment.

Key words: bilingual education, mathematics, English for special purposes, foreign students, interdisciplinary interaction.

Вступ. Останні роки для підвищення ефективності навчання іноземних студентів все частіше використовується підхід, заснований на білінгвальному навчанні. Він $є$ предметом обговорення в професійному суспільстві викладачів підготовчих факультетів різних закладів вищої освіти. Такий підхід тісно пов'язаний та узгоджений з міждисциплінарним підходом до викладання навчальних дисциплін і предметно-інтегрованим навчанням, що сприяє більш глибокому засвоєнню академічних дисциплін, підвищенню шансів отриманні якісної освіти іноземних студентів у закладах вищої освіти як у країні перебування, так і за її межами, а особливо коли мова йде про вивчення англійської мови для спеціальних цілей. Зокрема, уваги також потребують проблеми вивчення англійської мови для подальшого навчання в ЗВО європейських країн. Мова спеціальності також $€$ найголовнішим аспектом викладання української мови як іноземної в нефілологічних закладах вищої освіти (MES of Ukraine, 2013).

Навчання мови спеціальності багатоаспектне. У першу чергу воно неможливе без роботи над спеціальною термінологією (Savory, 1968), що спирається на лінгвістичний аналіз одиниць різних рівнів: термінологічних словосполучень, слів, елементів-термінів. Базою для аналізу одиниць різного рівня $€$ засвоєння мінімального переліку термінів окремої дисципліни. Вирішення цього завдання потребує розробки словника за предметом підготовки. Для забезпечення більш якісної підготовки його необхідно розробляти для більшості рідних мов студентів-іноземців.

Навчання іноземних студентів на початковому етапі їх підготовки носить явні ознаки білінгвального навчання (Moschkovich, 2002). У цій роботі описується досвід такого процесу з математики на підготовчому факультеті іноземних слухачів Харківського національного університету ім. В.Н. Каразіна. Освітній процес і оцінка навчальних досягнень іноземних слухачів здійснюються викладачами спеціальних дисциплін, зокрема математики, в тісній співпраці з викладачами української мови як іноземної мови.

Методи та методики дослідження. У роботі було застосовано 
теоретичні методи дослідження (аналіз та узагальнення психологопедагогічної літератури, навчальних планів, освітньо-професійних програм) та опрацювання практичного досвіду з організації та методики навчання математики студентів-іноземців.

Питання білінгвального навчання широко представлені в методичній літературі. Поряд з цим терміном уживаються такі: “двомовність”, "мовне занурення" або навіть “двомовне мовне занурення". Увагу дослідників привернули університетські програми для іноземних студентів, які здобувають спеціальність в умовах мовного занурення, найчастіше йдеться про англійську мову і людей (ELL, English Language Learners). Сьогодні продовжує свій розвиток "теорія мов для спеціальних цілей" (languages for special purposes), формуванню якої передували роботи Т. Сейворі (Savory, 1968: 295-301). Білінгвальне навчання математики іноземних студентів передбачає одночасне використання англійської мови та української мови в контексті математики та продовжує залишатися предметом педагогічних досліджень.

Найбільш популярною темою $€$ вага кожної 3 мов-партнерів. Деякі дослідники стверджують, що студенти показують кращі результати з тієї з мовпартнерів, якою вони користуються більше (Moschkovich, 2002; Clarkson, 1992; Davidson, 1990; Gomez, 2005). Безумовно, викладання дисципліни, що вивчається в білінгвальному режимі, має проходити 3 урахуванням особливостей базової навченості студентів та можливої індивідуалізації програми навчання. Як правило, однією з мов-партнерів $є$ англійська. Частка використання її залежить від того, наскільки високий рівень володіння нею в регіоні проживання студента (Moschkovich, 2007). У практиці роботи кафедри найбільш часте співвідношення мов 50/50, хоча може доходити до 70 й більше відсотків. Вибір моделі навчання та необхідності використання англійської мови залежить від особливостей контингенту студентів за роками набору. У деяких випадках, коли частка студентів, що володіють англійською мовою мала, навчання ведеться виключно на мові країни перебування. Хоча останнім часом все більший попит має навчання виключно англійською мовою.

Ряд викладачів як у нашій країні, так і за кордоном відзначають невисокий рівень підготовки з математики, зростання кількості іммігрантів, у яких до того ж є проблеми з мовою країни перебування (англійською в цьому випадку), так як вдома вони спілкуються виключно рідною мовою. Дослідники приходять до висновку, що математика набагато менше ніж інші дисципліни залежить від мови спілкування. Важливішими $є$ методи вивчення математики в країні походження студентів (англійська школа, китайська школа, школа французьких колоній) (LindholmLeary, 2008; Robertson, 2009). Проте білінгвальне навчання студентів-іноземців математиці послідовно сприяє засвоєнню ними розділів математики і застосування ними математичного апарату при вирішенні практичних, досяжних та індивідуально орієнтованих завдань (Setati, 2008; Moschkovich, 2012).

Білінгвальне навчання привертає увагу дослідників перш за все тому, що воно дозволяє краще організувати вивчення профільних дисциплін та 
компенсує брак знання однієї мови за рахунок другої, що в результаті надає студентам широкий вибір джерел інформації та способів навчання.

На жаль, знання англійської, української мови і математики в студентів неоднорідні. Частина слухачів мають достатній для навчання рівень володіння англійською мовою, але їх знання з математики недостатні. Інші мають хороші знання мови країни перебування, але погано підготовлені з математики або не знають англійської мови. $Є$ й ті, хто добре підготовлений з математики, але не знає ні англійської, ні російської мов.

Таким чином, не вирішеними досі залишаються питання формування методики викладання математики для забезпечення необхідних компетенцій у студентів для подальшого навчання в закладах вищої освіти України. Актуальною $є$ проблема створення освітнього середовища для організація якісної підготовки з математики.

Тому метою статті $€$ розробка методики вивчення математики іноземними студентами на основі білінгвального підходу з використанням сучасного освітнього середовища.

Результати та дискусії. Практичний досвід показує, що саме математика викликає найбільше ускладнення при вивченні студентами. При цьому рівень математичної підготовки абітурієнтів з різних країн украй неоднорідний, перш за все, через відмінності в змісті програм національних загальноосвітніх шкіл.

Ha першому практичному занятті 3 математики зазвичай проводиться діагностичне тестування 3 метою визначення вихідного рівня математичної підготовки студентів. Результати подібного тестування (максимально можна отримати 12 балів) представлені в таблиці 1 i, на нашу думку, є характерними.

Необхідність вирівнювання цього дисбалансу для того, щоб студенти-іноземці могли освоювати навчальні програми дисциплін спільно 3 першокурсникам-українцями, пояснює появу підготовчих факультетів у ЗВО України, які приймають іноземних громадян.

Наведені статистичні дані $€$ підставою для вибору методичних прийомів і технологій навчання в описуваному освітньому процесі (Davidson, 1990: 52-56).

Таблиця 1 - Рівень математичної підготовки студентів-іноземців

\begin{tabular}{|c|c|c|}
\hline Бали: & Кількість студентів (чол.) & $\%$ \\
\hline $10-12$ & 8 & $15 \%$ \\
\hline $7-9$ & 9 & $17 \%$ \\
\hline $4-6$ & 11 & $21 \%$ \\
\hline $0-3$ & $24(13)^{*}$ & $47 \%(25 \%)^{*}$ \\
\hline Разом: & 52 & $100 \%$ \\
\hline
\end{tabular}

Примітка: * - в дужках подано кількість студентів з нульовим початковим рівнем підготовки. 
Принципи відбору змісту навчального матеріалу для практичних занять з математики на підготовчому факультеті для іноземних слухачів обумовлені необхідністю ліквідувати значну різницю у вихідному рівні підготовки з математики, скоротити розрив між більш підготовленими і менш підготовленими студентами, познайомити слухачів із завданнями підвищеної складності.

Перший розділ курсу починається 3 введення основних математичних термінів: цифри і числа, математичні знаки, арифметичні дії; уточнюється поняття натуральних, цілих, раціональних і дійсних чисел. Далі вводяться поняття, які необхідні для вивчення фізики, хімії, а саме: відсотки, пропорції, тригонометричні функції.

Другий розділ присвячений числовим і алгебраїчним виразам, тотожним перетворенням раціональних і ірраціональних виразів, розв'язанню рівнянь та нерівностей. Як правило, початковий рівень слухачів дозволяє опрацювати такий значний обсяг дидактичних одиниць за досить короткий час.

У наступному розділі вводиться поняття функції без точного математичного визначення. Розглядаються такі основні поняття, як нулі функції, проміжки знакосталості, зростання/спадання і екстремуми функції, найбільше і найменше значення функції на проміжку, елементарні функції та їх графіки. Завдання, які виконуються в цьому розділі, не передбачають використання похідної, визначення відповідають рівню середньої школи.

Заключні розділи курсу є найбільш важливими саме для вивчення університетського курсу вищої математики. Це диференціальне й інтегральне обчислення, які $є$ ключовими на першому курсі університету незалежно від напряму підготовки.

Важливо підготувати слухачів до сприйняття великого обсягу усної інформації під час лекції, навчити їх не тільки розв'язувати, але й коректно пояснювати виконання завдань на практичних заняттях (Moschkovich, 2007: 158-166).

При роботі над упорядкуванням математичної термінологічної бази як українською, так і англійською мовою викладач математики повинен усунути різницю в рівні підготовки, при цьому особливо важливо дати особливості викладання математики в національній науковій школі і допомогти більш слабким студентам підготуватися до навчання на першому курсі бакалаврату.

Проблема недостатнього володіння мовою, якою здійснюється навчання, значно ускладнює освітній процес. Білінгвальний підхід дозволяє вирішити термінологічні проблеми, досягти кращого розуміння і прискорити досягнення бажаного рівня навченості неоднорідних за рівнем підготовки та країн походження груп слухачів.

Для іноземних студентів, які не володіють предметною компетенцією, українська мова $є$ частиною освітнього процесу - основним засобом набуття фаху. Оскільки в ієрархії мотивів вивчення іноземними студентами українській мові домінує навчально-професійна діяльність, 
абсолютно очевидно, що це й мова спеціальності, яка сприяє успішному навчанню іноземного студента у ЗВО, забезпечуючи можливість засвоєння предметів за фахом, складанню заліків та екзаменів.

3 вищевикладеного випливає, що поряд із загальною (етнічною) мовою студенти-іноземці повинні вивчати мову для спеціальних ціле 3 метою засвоєння професії. При цьому вивчення мови в обсязі, необхідному для розуміння художнього тексту (20\% навчального часу), відбувається одночасно з вивченням публіцистичної та наукової мови (80\% навчального часу) (Savory, 1968: 295-301).

Повернемося до досвіду викладання української мови, яка на підготовчому факультеті носить математичну спрямованість і $є$ типовим прикладом навчання іноземної мови. Завданням початкового курсу $є$ створення термінологічної бази, яка дозволила засвоєння в бакалавраті вищої математики та спеціальних дисциплін 3 достатньою часткою практичного розв'язання математичних завдань i застосування математичних методів у ході вивчення інформатики. Студенти мають навчитися: читати і розуміти символічний запис математичних виразів українською мовою; розуміти усну і письмову інформацію математичної тематики; вилучати з математичних аудіотекстів головну і другорядну інформацію, вміти записати ії символьно і переказувати усно; брати участь у діалогах з викладачем і однокурсниками, а також складати невеликі монологічні висловлювання на математичні теми; озвучувати свої дії при проведенні математичних обчислень, розв'язуванні задач, описувати зміни в процесі отримання проміжних результатів.

Слід зазначити, що частина випускників підготовчого фракультету вступає і в інші 3ВО, але все ж більшість з них стає студентами різних факультетів Харківського національного університету ім. В.М. Каразіна. Ті ж $з$ них, хто добре володіє англійською мовою, стають студентами спеціальностей, що викладаються англійською мовою. Програми навчання цих спеціальностей включають природничі й математичні дисципліни, які викладаються англійською мовою. Однак за умови лексичних труднощів застосовується білінгвальний підхід і мовоюпартнером використовується українська, що підвищує ефрективність засвоєння дисциплін.

Процес навчання мови спеціальності виключає поєднання занять за фрахом та носить попереджувальний характер, має своєю кінцевою метою формування в іноземних студентів мовної компетенції, достатньої для читання текстів підручників з фахових дисциплін, прослуховування лекцій викладачів, участі в семінарських заняттях, виконання завдань зі спеціальних предметів в усній і письмовій формі.

Ситуація ускладнюється тим, що формування предметної компетенції розділене: за мовну компетенцію "відповідальний" викладачфілолог, а за предметну - викладач-“предметник”. Це розмежування стало вже традиційним, і багато зусиль витрачається на узгодження навчальних дій викладачів, встановлення міжпредметних зв'язків, наступність. 
Кожен викладач математики, який використовує білінгвальний підхід, знає, яка велика роль англійської мови в навчанні іноземців математиці. Це саме та область, де потрібна міждисциплінарна співпраця і навіть робота в команді, яка останнім часом набула популярності в роботах фахівців з професійної лінгводидактики. На кафедрі реалізується підхід розробки білінгвальних підручників, а в деяких випадках три- і більше - лінгвальний підхід, де окремі елементи тексту та окремих понять перекладаються та наводяться рідною мовою студентів-іноземців.

Проте для багатьох викладачів математики поєднання викладання математики з білінгвальним підходом є проблемою, тому що далеко не всі вони володіють англійською мовою на потрібному рівні. 3 метою забезпечення підготовки іноземних студентів в університеті створені курси з вивчення англійської мови та курси підвищення кваліфікації викладачів. На фракультеті підготовки іноземних студентів проводяться міжкафедральні та методичні засідання, на яких обговорюються та узгоджуються підходи до білінгвальної підготовки студентів.

Висновки. Застосування білінгвального підходу до навчання i міждисциплінарної співпраці дозволяє іншомовним студентам: краще розуміти зміст досліджуваної дисципліни; отримати більше можливостей для уточнення важких моментів; розширити можливості спільної діяльності і роботи в команді для вироблення спільних рішень; комфортніше почуватися при роботі з математичним апаратом.

Серед переваг білінгвального навчання слід відзначити академічні успіхи студентів; більш упевнене використання в навчальній діяльності та для особистого спілкування англійської мови; кращі перспективи кар'єрного зросту; можливість участі в міжнародних заходах; участь у професійно-орієнтованому тестуванні для отримання міжнародних сертифікатів. На подальших рівнях навчання вільне використання математичного апарату англійською мовою дозволить студентам більш ефективно аналізувати конкретні ділові ситуації і приймати рішення, підтверджені обчисленнями.

Проведене дослідження не залишає сумнівів, що білінгвальне навчання є продуктом тісної співпраці викладачів базових дисциплін 3ВО, зокрема математики, і викладачів української та іноземних мов. Як показує практичний досвід, при вивченні іноземними студентами математики викладач відчуває труднощі як освітнього, так і корпоративного порядку, а саме: наявність мовного бар'єру; відмінність систем освіти і організації освітньої діяльності; відмінність у методології та методиці навчання математики.

Таким чином, використання білінгвального підходу до організації освітнього процесу при вивченні математики забезпечує узгодження між контентно-інтегрованим навчанням, та між особистісними здібностями іноземних студентів. Білінгвальне навчання виявилося найбільш придатним і ефективним методом для підготовки іноземних слухачів 3 різним рівнем володіння математикою і різними мовами спілкування. Міждисциплінарна взаємодія в процесі навчання, при якій учні отримують 
як професійний розвиток, так і покращують свої знання іноземної мови, заслуговує на позитивну оцінку i може бути рекомендовано до застосування при розробці освітнього середовища.

\section{Література}

1. Деякі питання організації набору та навчання (стажування) іноземців та осіб без громадянства МОН України; Наказ від 01.11.2013 № 1541.

2. Savory, T. H. (1968). The act of translation. Cape.

3. Moschkovich, J. (2002). A situated and sociocultural perspective on bilingual mathematics learners. Mathematical thinking and learning, 4(2-3), 189-212.

4. Clarkson, P. C. (1992). Language and mathematics: A comparison of bilingual and monolingual students of mathematics. Educational Studies in Mathematics, 23(4), 417-429.

5. Davidson, N. (1990). Cooperative Learning in Mathematics: A Handbook for Teachers. Addison-Wesley Publishing Company, Inc., Addison-Wesley Innovative Division, 2725 Sand Hill Rd., Menlo Park, CA 94025.

6. Gomez L. Dual Language Education: A promising 50-50 model / L. Gomez, D. Freeman, Y. Freeman // Bilingual Research Journal. - 2005. - Vol. 29, n.1, 145-164.

7. Moschkovich, J. (2007). Using two languages when learning mathematics. Educational studies in Mathematics, 64(2), 121-144.

8. LindholmLeary K. (2008). Language development and academic achievement in two-way immersion programs / K. LindholmLeary, E. Howard // TW Fortune \& DJ Tedick (Eds.), Pathways to Multilingualism: Evolving Perspectives on Immersion Education. - Oxford, UK: Blackwell, 177-200.

9. Robertson, K. (2009). Math instruction for English language learners. Retrieved April, 21, 2010.

10. Setati, M. (2008). Access to mathematics versus access to the language of power: The struggle in multilingual mathematics classrooms. South African Journal of Education, 28(1), 103-116.

11. Moschkovich, J. (2012). Mathematics, the Common Core, and language: Recommendations for mathematics instruction for ELs aligned with the Common Core. Commissioned papers on language and literacy issues in the Common Core State Standards and Next Generation Science Standards, 94, 17.

12. Berdnik P. G. (2018). Interactive Augmentation of Learning Environment for International Students, 34, 1378-1399.

\section{References}

1. Deiaki pytannia orhanizatsii naboru ta navchannia (stazhuvannia) inozemtsiv ta osib bez hromadianstva [Some issues of recruitment and training (internship) for foreigners and stateless persons] MES of Ukraine; Order from 01.11.2013 № 1541.

2. Savory, T. H. (1968). The act of translation. Cape.

3. Moschkovich, J. (2002). A situated and sociocultural perspective on bilingual mathematics learners. Mathematical thinking and learning, 4(2-3), 189-212.

4. Clarkson, P. C. (1992). Language and mathematics: A comparison of bilingual and monolingual students of mathematics. Educational Studies in Mathematics, 23(4), 417-429.

5. Davidson, N. (1990). Cooperative Learning in Mathematics: A Handbook for Teachers. Addison-Wesley Publishing Company, Inc., Addison-Wesley Innovative Division, 2725 Sand Hill Rd., Menlo Park, CA 94025. 
6. Gomez L. Dual Language Education: A promising 50-50 model / L. Gomez, D. Freeman, Y. Freeman // Bilingual Research Journal. - 2005. - Vol. 29, n.1, 145-164.

7. Moschkovich, J. (2007). Using two languages when learning mathematics. Educational studies in Mathematics, 64(2), 121-144.

8. LindholmLeary K. (2008). Language development and academic achievement in two-way immersion programs / K. LindholmLeary, E. Howard // TW Fortune \& DJ Tedick (Eds.), Pathways to Multilingualism: Evolving Perspectives on Immersion Education. - Oxford, UK: Blackwell, 177-200.

9. Robertson, K. (2009). Math instruction for English language learners. Retrieved April, 21, 2010.

10. Setati, M. (2008). Access to mathematics versus access to the language of power: The struggle in multilingual mathematics classrooms. South African Journal of Education, 28(1), 103-116.

11. Moschkovich, J. (2012). Mathematics, the Common Core, and language: Recommendations for mathematics instruction for ELs aligned with the Common Core. Commissioned papers on language and literacy issues in the Common Core State Standards and Next Generation Science Standards, 94, 17.

12. Berdnik P. G. (2018). Interactive Augmentation of Learning Environment for International Students, 34, 1378-1399.

\section{АНОТАЦІЯ}

У статті розглядаються особливості навчання математики іноземних студентів, які використовують англійську мову як посередницьку для двомовної освіти в Навчально-науковому інституті міжнародної освіти Харківського національного університету імені В. H. Каразіна. Проаналізовано процес попереднього оцінювання іноземних студентів, навчальну програму та логіку ї створення. У ній описано процес організації двомовної освіти іноземних студентів на факультеті та його координацію між викладачами. Представлено статистичний аналіз складу студентів, їх початкового рівня підготовки та обгрунтовано найбільш ефрективну стратегію викладання з використанням можливостей викладачів університету. Розглядається процес створення програми $з$ дисципліни «Математика» з урахуванням того факту, що студенти мають різний початковий рівень знань з математики. За допомогою статистики розроблено методику для математиків та іноземних студентів на основі комплексного підходу до інтересів сучасного середовища. 3 переваг двомовної освіти слід виділити академічний успіх студентів; більш упевнене використання англійської мови в навчальній діяльності та для особистого спілкування; найкращі перспективи кар'єри; можливість брати участь у міжнародних заходах та професійному тестуванні для отримання міжнародних сертифрікатів. На подальших етапах навчання вільне використання англійської математичної мови дозволить студентам більш ефективно аналізувати конкретні бізнес-ситуації та приймати рішення, перевірені розрахунками. Таким чином, використання двомовного підходу до організаціі навчально-виховного процесу при вивченні математики забезпечує вирівнювання між змістовно-інтегрованим навчанням та між особистими здібностями іноземних студентів. Двомовна освіта була найбільш підходящим та ефективним методом підготовки іноземних студентів з різним рівнем математики та різними мовами спілкування. Міждисциплінарна взаємодія в процесі навчання, в якому студенти отримують як професійний розвиток, так і вдосконалення своїх знань з іноземної мови, заслуговує на позитивну оцінку і може бути рекомендована для використання у навчальному середовищі.

Ключові слова: білінгвальне навчання, математика, англійська мова для спеціальних цілей, іноземні слухачі, міждисциплінарна взаємодія. 